\title{
Packaging Design Model Of Talang Salted Fish Processing Industry Using Value Engineering Method
}

\author{
A Amri ${ }^{1}$, Saifuddin Muhammad Jalil ${ }^{2 *}$, Syamsul Bahri ${ }^{1}$, Fatimah ${ }^{1}$ \\ ${ }^{1}$ Department of Industrial Engineering, Universitas Malikussaleh, Aceh, Indonesia \\ ${ }^{2}$ Department of Electrical Engineering, Universitas Malikussaleh, Aceh, Indonesia \\ *Corresponding author E-mail: saifuddin@unimal.ac.id
}

Manuscript received 29 October 2021; revised 10 Nov 2021; accepted 1 Jan 2022. Date of publication 10 Jan 2022

\begin{abstract}
One of the products that need attention, especially related to packaging, is the Talang Salted Fish product, which has been selling Talang Salted Fish without using packaging. So that this study aims to design the packaging of talang salted fish to add selling value which can later be an attraction for consumers to buy it. The method used is value engineering and the analytical hierarchy process (AHP). The value engineering method is applied to increase the value, performance, and cost of packaging design consisting of brand criteria, net weight measurement, product identity, attractiveness, color suitability, typography, and font size. The Analytical Hierarchy Process method is applied at the analysis stage to help determine the priority criteria in accordance with the wishes of consumers. The results showed that the alternative design with the highest performance value was alternative 1 (A-B-D-E), namely the design with packaging materials made of transparent plastic, the colors used were bright, the packaging was rectangular and all capital letters were used. This selected alternative design has a value of 0.039 . This value is obtained from the performance of 38.9 and the cost of Rp. 1000 per pack.
\end{abstract}

Keywords: Packaging Design, Talang Salted Fish, Value Engineering, Analytical Hierarchy Process.

\section{Introduction}

Pusong Village, Lhoseumawe City is a large fish-producing area in the Lhokseumawe city area, but the people in Pusong Village, especially the fishermen tribe, lack the knowledge to innovate the packaging of processed salted fish products into modern salted fish packaging. The absence of modern packaging forms and only using transparent and unlabeled plastic bags as containers has risks that affect the quality and durability of food. So that the lack of product attractiveness and considering the large number of talang salted fish in the village of Pusong, Lhokseumawe city makes researchers interested in adding to the selling value of the packaging design of processed talang salted fish which can later become an attraction. for consumers to buy [1].

This study aims to design talang salted fish packaging to increase the selling value which can later be an attraction for consumers to buy it. With this attractive design, tourists will also become buyers of souvenirs in the form of talang salted fish in Pusong village, it is necessary to design an attractive talang salted fish packaging, accurate information about color, taste that is maintained when traveling. , etc. other.

The packaging of a product can have an important influence in maintaining or increasing sales. For food products, packaging is made to protect the contents from external contamination such as substances that can damage the taste, shape, and suitability of consumption and increase the selling value of the product. Packaging has an important meaning in influencing consumers directly or indirectly in determining the choice of products to be purchased [2], [3].

The method used is value engineering. The value engineering method is applied to increase the value, performance, and cost of packaging design consisting of brand criteria, net weight measurement, product identity, attractiveness, color suitability, typography, and font size [4], [5] [6] [7].

Previous studies that are closely related to this research are as follows:

Department of Industrial Engineering, Indragiri Islamic University, her research is entitled "Proposed Packaging of Salted Lome Fish (Harpodon Nehereus) Using the Value Engineering Method" [8] [9]. The variables used are packaging and cost functions. This study concludes that there is an increase in the value of packaging design using the value engineering method, which is an increase of $17.284 \%$ and there is a significant difference between the old packaging design and the first packaging design which has the highest value [10] 
[11]. by $86.81 \%$. Comparison of the cost of different designs between the old packaging design and the new packaging is Rp. 300 where the page packaging design costs Rp. 500 and a new packaging design for Rp. 800, but has different benefits, where the benefits of the new billboard design are more attractive and suitable for use as packaging for salted lome fish in "UMKM Padaidi" based on the results of the completed questionnaire disseminated [7] [12].

\section{Literature Review}

\subsection{Definition of Value Engineering}

Value Engineering (VE) is an efficient method for obtaining alternatives with the lowest cost and specific performance. Value engineering according to Ulrich is an organized effort that is shown to analyze the functions of goods and services for the purpose of achieving basic functions at the lowest total cost, consistent with the achievement of important characteristics. Meanwhile, according to Milles, value engineering is a creative and systematic approach with the aim of reducing or eliminating unnecessary costs. Management techniques that use a systematic approach to achieve functional continuity are the best balance between cost, reliability, and system or project performance. So, Value Engineering is an evaluation method that analyzes the engineering and value of a project or product involving owners, planners, and experienced experts in their respective fields with different systematic and creative approaches aimed at producing constant quality at a cost. as low as possible. , that is, with functional limitations and task planning stages that can identify and eliminate unnecessary or unsupported costs and effort. Value Engineering is not the process of making things cheap or cutting prices by reducing appearances. Nor is it a control over quality or review of project or product planning [13].

\subsection{Fungsional Analisis System Technique}

The System Functional Analysis (FAST) technique is a systematic diagramming technique for identifying functions and describing the interrelationships between these functions[14]-[17]. Functions are expressed as a combination of a verb and a noun. Some of the terms used at Metlife FAST include. What are the boundaries of the discussion of the problems at hand. In the FAST diagram, it is shown as an area bounded by two vertical lines delimited by a high-level and a low-level function, respectively. FAST charts are organized according to a hierarchy of functions. High-level functions are placed on the left while low-level functions are placed on the right. Making FAST diagrams usually starts from the basic functions that have been determined. Basic functions are within the scope of the problem to be discussed, while low-level functions are outside the scope of the problem. The preparation of the FAST diagram function is carried out using two questions, namely "how (how)" and "why (why)". The arrangement of functions on the FAST diagram can be seen in the following figure $1[18]$.

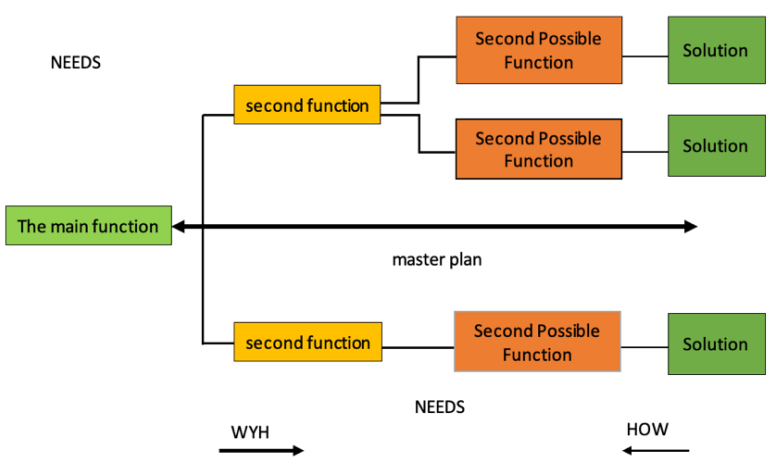

Fig 1. Diagram of system function analysis techniques

\subsection{Analytical Hierarchy Process Method}

The Analytical Hierarchy Process (AHP) was developed by Dr. Thomas L. Saaty of the Wharton School of Business in the 1970s to organize information and judgment in selecting the most preferred alternative. By using AHP, the problem must be solved in an organized frame of mind, so that it is possible to be expressed in order to make effective decisions about the problem. Complex problems can be simplified and speed up the decision-making process [13], [19].

AHP developed by Thomas L. Saaty can solve a fairly complex problem where the number of aspects or criteria that exist is sufficient. This complexity can also be caused by the structure of the problem that has not been clearly developed, perceptual uncertainty in decision making, and the unavailability of accurate or non-existent statistical data. Sometimes problems arise and you have to make a decision as soon as possible to solve the problem is not possible to record directly numeric.

Graphically, the AHP decision problem can be constructed as:

A multilevel chart begins with an objective/objective, with first-level criteria, sub-criteria, and finally alternatives. AHP allows the user to assign a relative weight value of several criteria (or several alternatives). against the criteria) intuitively by doing pairwise comparisons Dr. Thomas L. Saaty, maker of AHP then determine a consistent way to convert the pairwise comparisons, into a set of numbers representing relative priority of each criterion and alternative. AHP has many advantages in explaining the decision-making process because it can describe it graphically so that it can be understood by all parties involved in decision-making. With AHP, complex decision processes can be broken down into smaller decisions that can be handled more easily. In the application of the AHP method which prioritizes the quality of data from respondents, and does not depend on quantity[20]-[22].

\section{Methods}

\subsection{Types and Sources of Data}

To get the data needed, researchers came directly to the Pusong Market, Lhokseumawe City, especially at UD. Wirna, Jl. KP3 Lhokseumawe City to see live fish sales. Talang salted fish design is included in the joint study because this design uses qualitative and 
quantitative data. The data used for the analysis was obtained by collecting primary data and secondary data according to the needs of data analysis.

\subsection{Data Collection Techniques}

There are several methods used in collecting data on this packaging design proposal, namely:

1. Literature research, namely by reading references, books, journals, works, the internet or literature that has to do with the theoretical basis.

2. (Observation) is collecting data in the field by seeing and observing the object of research directly by recording data and matters related to research.

3. Documentation is a method of collecting data owned by the source concerned.

4. Interviews, namely data in the form of opinions obtained from actors and parties with an interest in operations regarding salted fish packaging, capital, market, capital, and the necessary information.

5. Questionnaire is a set of statements submitted to be submitted to respondents. This questionnaire aims to obtain written information from respondents related to the research objectives. The questionnaire in this study consisted of:

a. This open-ended questionnaire was used as a preliminary study to help understand the attributes of the salted fish packaging design according to the consumer's wishes. The number of respondents for the distribution of this open questionnaire is 40 respondents.

b. Closed questionnaire, namely brainstorming the results of the search for consumer needs on an open questionnaire that identified variables and benchmarking products with respondents. This closed questionnaire was distributed to 40 respondents. The assessment on a closed questionnaire uses a Likert scale, which is to see the level of respondents' approval of a question. The Likert scale has a gradation from very positive to very negative, including Strongly Agree (SS): 5, Agree (S): 4, Uncertain (R): 3, Disagree (TS): 2, Strongly Disagree (STS) : 1

\subsection{Analysis Method}

The analytical method used in Value Engineering (VE) or value engineering in the design of talang salted fish packaging is to use the Standard Job Plan which consists of several stages or stages as follows[5], [8], [13], [23]-[30]

1. Information Phase

The information stage aims to collect information needed in product improvement, such as consumer needs, prices, product functions, materials, advantages, and disadvantages of existing products, and so on, as well as the use of FAST diagrams. Information was obtained by means of interviews, observations, and questionnaires. In this phase, all kinds of information about products and buyers and things needed for value engineering methods are collected. Then tested the validity and reliability using software.

2. Creative Phase

This phase is a phase of generating creativity which is carried out using creativity techniques. At this stage, it can be started when the desired function has been determined.

3. Analysis Phase (Judgement Phase)

The analysis stage is intended to evaluate all the alternatives that appear so that they can be used as a basis for choosing the best alternative. The calculation of the hierarchical weight factor of all criteria is carried out to determine the level of importance of a criterion against other criteria. This calculation uses Expert Choice 11 software. This phase is an evaluation phase of the alternatives generated from the creative phase so that it can be known which alternative will be used for further research. In this study, the method used is to increase the function twice and the cost to increase once by the formula:

$$
V \uparrow=\frac{F \uparrow \uparrow}{C \uparrow}
$$

This means that to increase the selling value of talang salted fish, it is necessary to improve the packaging function by increasing the cost of packaging design.

4. Development Phase

This phase is a phase of deeper assessment of the alternatives selected through the analysis phase that can be carried out by considering technical and economic factors.

5. Presentation and Recommendation Stage

This phase is a presentation or presentation to decision makers about what has been developed and what has been recommended in the development phase.

\section{Results and Discussion}

In this study, to obtain the desired talang salted fish packaging, customer voice data was needed through the distribution of open questionnaires, closed questionnaires, and paired questionnaires (AHP).

1. Open Questionnaire Results

The results of the open questionnaire distributed to 40 respondents are summarized in table 1 below.

Table 1. Open Questionnaire Design Data for Talang Salted Fish Packaging

\begin{tabular}{lllll}
\hline \multicolumn{1}{c}{ Primery } & \multicolumn{1}{c}{ Attribute } & Tertiary \\
\hline Design & \multicolumn{1}{c}{ Secondary } & Shape \\
\cline { 2 - 4 } & 2 & Packaging Colors & - Light colors \\
& & - Simple & \\
\hline
\end{tabular}




\begin{tabular}{|c|c|c|c|}
\hline & 5 & Packaging dimensions & $\begin{array}{l}\text { Net weight } 500 \text { gr. } \\
\text { Length and width are adjusted according to net weight. }\end{array}$ \\
\hline & 6 & Ornaments & $\begin{array}{l}\text { - Own a Trademark } \\
\text { - Sewer fish pictures } \\
\text { - Net weight information }\end{array}$ \\
\hline Material & 7 & Packaging & Transparent Plastic \\
\hline \multirow[t]{2}{*}{ Multi Function } & 9 & Main function & Packaging \\
\hline & 10 & Addittional functions & $\begin{array}{l}\text { - Attractiveness and Aesthetics } \\
\text { - Product durability } \\
\text { - Minimize odor when carried }\end{array}$ \\
\hline
\end{tabular}

Source: Data Collection

After an open questionnaire was conducted, then a closed questionnaire was conducted which was distributed to 40 respondents. Data from paired questionnaires (AHP) for respondents 7. Geomean calculation to get a paired matrix is to fill in the blank boxes, one of which is divided by a pair of matrices so that the results of the recapitulation of the probability or geomean of each criterion can be seen in table 2 below:

Table 2. Matrix of probability comparison between criteria

\begin{tabular}{|c|c|c|c|c|c|c|c|}
\hline Criteria & Dadang brand & $\begin{array}{c}\text { Measures net } \\
\text { weight Product }\end{array}$ & $\begin{array}{c}\text { identity } \\
\text { Attractive }\end{array}$ & interesting & $\begin{array}{c}\text { Appropriate } \\
\text { color }\end{array}$ & Typography & Font size \\
\hline Trademark & 1,000 & 1,170 & 0,381 & 1,426 & 1,919 & 1,486 & 1,104 \\
\hline Net weight measure & 0,855 & 1,000 & 0,295 & 1,219 & 1,952 & 1,219 & 2,246 \\
\hline Product identity & 2,627 & 3,394 & 1,000 & 2,627 & 3,536 & 2,521 & 2,950 \\
\hline Interesting & 0,701 & 0,820 & 0,381 & 1,000 & 1,104 & 1,219 & 1,346 \\
\hline Color match & 0,521 & 0,512 & 0,283 & 0,906 & 1,000 & 0,635 & 1,000 \\
\hline Typography & 0,673 & 0,820 & 0,397 & 0,820 & 1,575 & 1,000 & 1,919 \\
\hline Font size & 0,906 & 0,445 & 0,339 & 0,743 & 1,000 & 0,521 & 1,000 \\
\hline
\end{tabular}

Source: Data Collection

\section{Analysis Model}

After all the necessary data, both primary and secondary data, have been collected, then data processing and analysis are carried out. The analysis used is by using a value engineering approach which consists of five stages, namely the Five-Stage Work Plan.

\section{Information Stage}

At this stage, the results of the information obtained regarding the initial product will be described which will be used as a reference in making the design of the Talang salted fish packaging. Talang salted fish can be seen in figure 2 and the plastic container for Talang salted fish is in figure 3 .

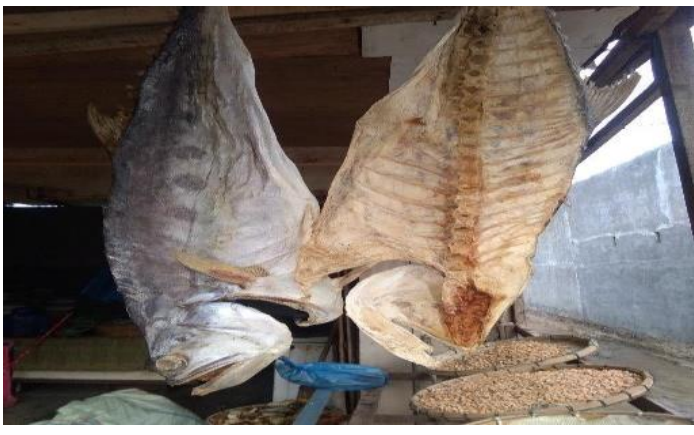

Fig 2. Talang salted fish Figure

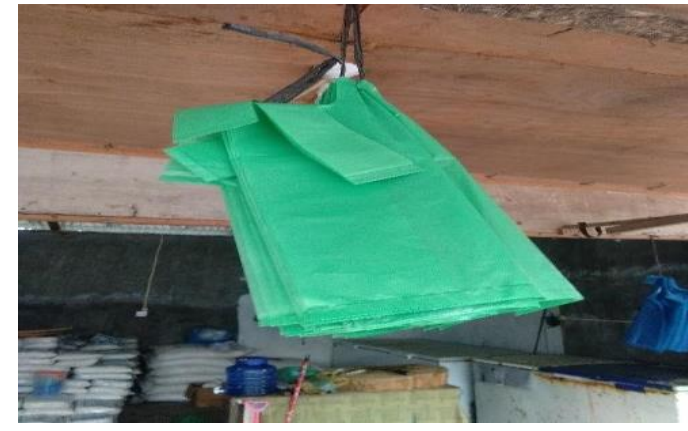

Fig 3. Plastic container for Talang salted fish

Figure 2 is talang salted fish that is sold at the pusong market while figure 3 is a plastic container that is used as a talang salted fish container if there are consumers who buy it. And from the results of the distribution of open questionnaires that have been carried out on 40 respondents, it was found that the sale of salted fish without packaging has the following shortcomings.

- Less attractive

- Does not have a product identity

- Does not have a trademark

- Less hygienic

- Less durable 
A. Validation and Reliability Test

From the results of the analysis of the score value of the statement with the total score, then we compare it with the value of $\mathrm{r}$ table. The value of $\mathrm{r}$ table at $5 \%$ is significant with a 2 -sided test and $\mathrm{n}=40$, then the $\mathrm{r}$ table can be 0.3120 . From Table 2 . it can be seen that all statements in the closed questionnaire are valid ( $\mathrm{r}$ count $>\mathrm{r}$ table).

From the results of the reliability analysis obtained an alpha value of 0.716 , while the critical $\mathrm{r}$ value at $5 \%$ significance with a two-sided test and $n=98(\mathrm{df}=\mathrm{n}-2=38)$ of 0.320 . This is evidenced by the critical $\mathrm{r}$ value $>$ the critical table $\mathrm{r}$ value $(0.712>0.320)$.

B. Function Analysis System Technique Method

The unction Analysis System Technique (FAST) method is a systematic diagramming technique for identifying functions and describing the relationships between these functions. The results of brainstorming consumer needs and product benchmarking can identify the functions needed in the talang salted fish packaging design, which can be seen in Figure 4. below

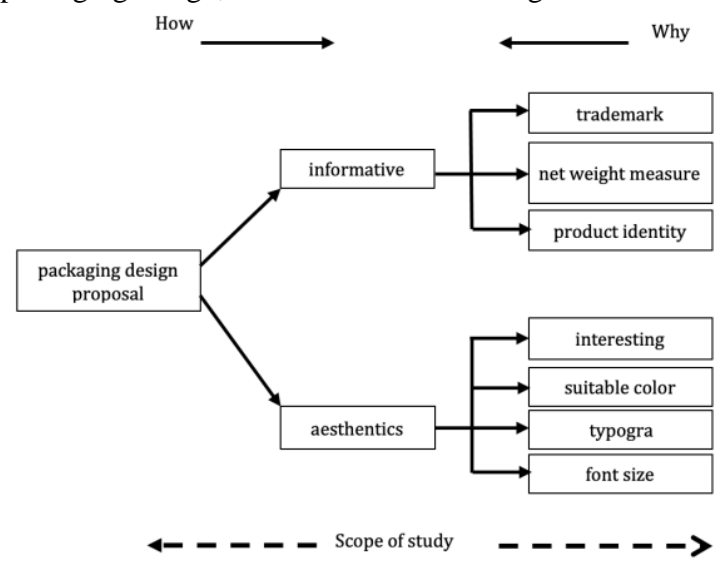

Fig 4. FAST diagram of the proposed Talang salted fish packaging design

From the results of the FAST diagram in Figure 4 above, it is known that the main function of the Talang salted fish packaging design is to package the product. And from the main function obtained 9 derivative functions. From the derived function obtained, it is then equipped with an objective function. The objective function describes the requirements of the secondary function.

\section{Creative Phase}

At this stage raises 7 criteria with 1 goal. This stage describes several alternatives that are prioritized based on an agreement between researchers and consumers on the alternatives that are raised. At this stage, various criteria and the weight of each criterion are made using the AHP method as a decision-making process that is considered to be assessed. The hierarchical structure of the Talang salted fish packaging design can be seen in Figure 5. below:

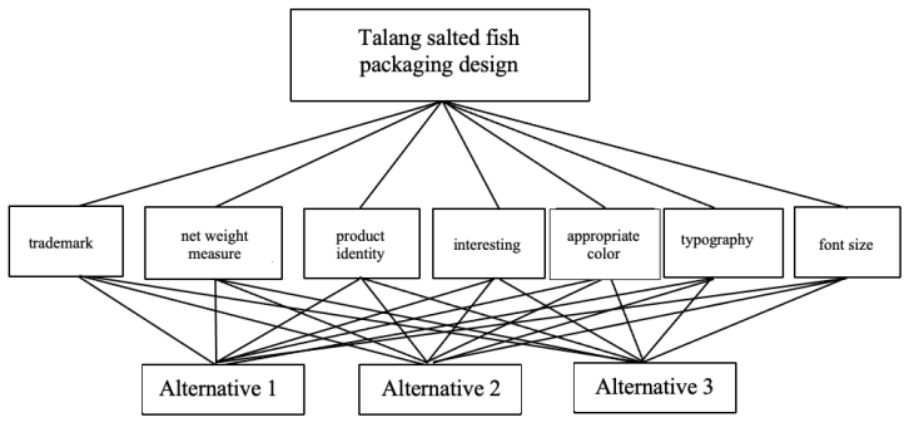

Fig 5. Hierarchical Structure of Talang Salted Fish Packaging

C. Alternative generator design

The alternative design generator is obtained based on the results of brainstorming against the criteria that consumers want and is a physical condition that represents the function and criteria of the packaging design itself. The results of the Morphology Chart packaging design can be seen in Table 3. as follows:

Table 3. Packaging Design Morphology Chart

\begin{tabular}{clcc}
\hline No & Element & Alternative & \\
& & A & \\
\hline 1 & Packaging material & B & C \\
\hline 3 & Color of packaging design & D & \\
\hline 4 & Packaging shape & E & F
\end{tabular}

Source: Data Processing 
3 Phases of Analysis

At this stage, design alternatives will be evaluated and analyzed so that the selected design is obtained. From the design alternatives that have been obtained at the creative stage, three alternative designs will be designed, namely:

1. Alternative 1 (A-B-D-E)

- The packaging material is made of transparent plastic (A)

- The color used is light shade (B)

- Rectangular packaging (D)

- Use all capital letters in product identity (E)

2. Alternative 2 (A-C-D-E)

- The packaging material is made of transparent plastic (A)

- The color used is dark color (C)

- Rectangular packaging (D)

- Use all capital letters in product identity (E)

3. Alternative 3 (A-B-D-F)

- The packaging material is made of transparent plastic (A)

- The color used is light shade (B)

- Rectangular packaging (D)

- Using capital letters and lowercase letters on product identity $(\mathrm{F})$

Furthermore, an assessment of the value of various alternatives and criteria is carried out in the following Table 4.

Table 4. Assessment of criteria and alternative scores

\begin{tabular}{lcccc}
\hline Criteria / Alternative & Alternative 1 & Alternative 2 & Alternative 3 & Total \\
\hline Trademark & 0,421 & 0,301 & 0,278 & 1.000 \\
\hline Net weight measure & 0,378 & 0,301 & 0,321 & 1.000 \\
\hline Product identity & 0,367 & 0,322 & 0,311 & 1.000 \\
\hline Interesting & 0,431 & 0,206 & 0,363 & 1.000 \\
\hline Color match & 0,417 & 0,294 & 0,290 & 1.000 \\
\hline Typography & 0,401 & 0,327 & 0,272 & 1.000 \\
\hline Font size & 0,356 & 0,333 & 0,312 & 1.000 \\
\hline
\end{tabular}

Source: Data Processing

After getting the value of the assessment of each criterion against the alternative, normalization is carried out, and a comparison of the consistency index (CI) and the inconsistency ratio (RI) is calculated using Expert Choice 11 software. To check the data inconsistency ratio, the inconsistency ratio value in each matrix comparison is in table 5.

Table 5. Ratio of inconsistency of comparison between criteria against alternatives

\begin{tabular}{cll}
\hline No. & \multicolumn{1}{c}{ Element Comparison Matrix } & CR Value \\
\hline 1 & Comparison of trademark criteria & 0,00036 \\
\hline 2 & Comparison of the criteria for the size of the net weight & 0,03 \\
\hline 3 & Product identity criteria comparison & 0,00104 \\
\hline 4 & Interesting criteria comparison & 0,00072 \\
\hline 5 & Comparison of appropriate color criteria & 0,10 \\
\hline 6 & Typographic criteria comparison & 0,09 \\
\hline 7 & Comparison of font size criteria & 0,00104 \\
\hline Source: Data processing
\end{tabular}

It can be concluded that the pairwise comparisons given by expert respondents have a smaller inconsistency ratio value of 0.1 as the maximum limit of the inconsistency ratio value. Thus the results of the combined geometric calculation of the respondent's data are quite consistent. The results of the recapitulation of the performance of the three alternatives can be seen in table 6 . below:

Table 6. Performance Calculation

\begin{tabular}{clc}
\hline Alternative & Pn & Rank \\
\hline Alternative 1 & 38,9 & 1 \\
\hline Alternative 2 & 30,4 & 3 \\
\hline Alternative 3 & 30,7 & 2 \\
\hline
\end{tabular}

Source: Data processing

From the calculation results, it is known that the alternative that has the greatest performance is alternative 1 (ABDE) with the following specifications: packaging material made of transparent plastic, bright colors used, rectangular packaging, and all capital letters. letters are used. This alternative is then considered for production compared to other alternatives.

Development Phase

Calculation of font size so that the new packaging design is easier to read by consumers, and in this study using a viewing distance of 3 meters or $300 \mathrm{~cm}$ from the object of research. The results of the calculation of the font size can be seen in Table 7 below: 
Table 7. Calculation of font size

\begin{tabular}{lll}
\hline No & Type & Size \\
\hline 1 & Letter Height $(\mathrm{H})$ & $1,5 \mathrm{~cm}$ \\
\hline 2 & Font Bold & $0,25 \mathrm{~cm}$ \\
\hline 3 & Distance of Two Letters/Numbers & $0,3 \mathrm{~cm}$ \\
\hline 4 & Lowercase Height & $1 \mathrm{~cm}$ \\
\hline 5 & Letter Width & $1 \mathrm{~cm}$ \\
\hline 6 & Two Words Distance & $1 \mathrm{~cm}$ \\
\hline
\end{tabular}

Source: Data processing

\section{Cost analysis}

The following details the costs that need to be incurred for the manufacture of talang salted fish packaging can be seen in the table below. Selected alternative (alternative 1)

Table 8. Design costs of selected alternative designs (alternative 1)

Material and Labor Cost

Price Per Unit (IDR)

\begin{tabular}{lc}
\hline Plastic Screen Printing Price & 300 \\
\hline Price Transparent plastic size $25 \times 38$ & 400 \\
\hline Price of packing fee & 300 \\
\hline Total & 1000 \\
\hline
\end{tabular}

Source: Market research

- Alternative considerations (alternative 2 and alternative 3 )

Calculation of value

The last stage of value engineering is to determine the value obtained from the performance score divided by the cost per product on each alternative.

Table 9. Results of determining the value (value)

\begin{tabular}{ccccc}
\hline Alternative to - & Cost per package (IDR) & Performance Score & \multirow{2}{*}{ value } & Rank \\
\hline 1 & 1000 & 38,9 & 0,039 & 1 \\
\hline 2 & 1000 & 30,4 & 0,030 & 3 \\
\hline 3 & 1000 & 30,7 & 0,031 & 2 \\
\hline
\end{tabular}

Source: Data processing

Based on the results of determining the value of each of the alternatives above, it can be analyzed that the highest value is alternative 1 with a value of 0.039 so that alternative 1 is an alternative that must be generated because it is in accordance with that value. engineering methods and in accordance with the criteria of consumer desires.

\section{Function Value}

Based on the results of the calculation of the function value for the selected alternative, namely alternative 1 (A-B-D-E) of 0.039 . Selected design alternative (A-B-D-E). Pictures of the selected talang salted fish packaging design proposals can be seen in Figures 6; 7 ,and 8 below:

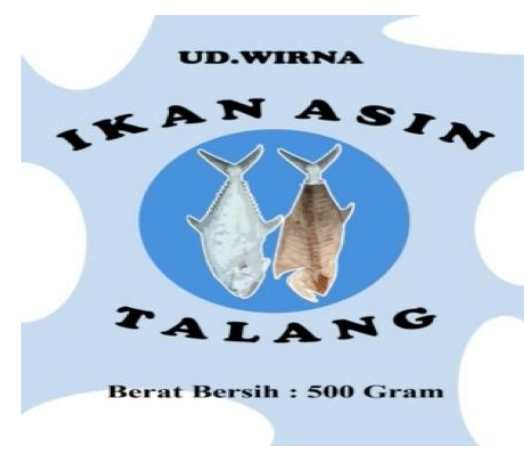

Fig 6. Proposed packaging design

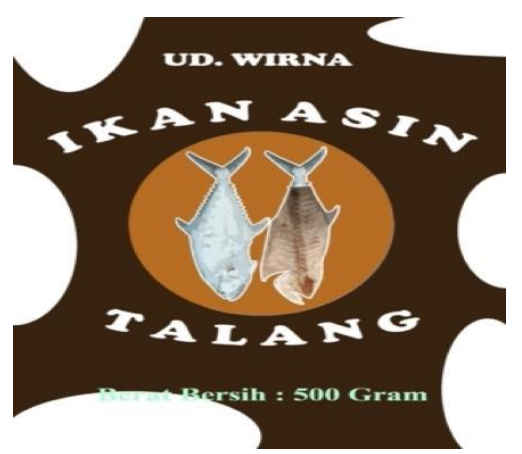

Fig 7. Proposed alternative design 2 
Selected talang salted fish packaging

Recommendation Phase

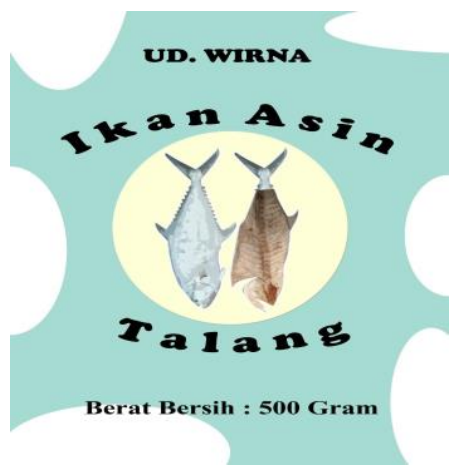

Fig 8. Suggested alternative designs for 3 packages of salted fish talang

By calculating and simulating the selected packaging design trials, the following results are obtained:

1. The packaging design made using the selected design has a length of $38 \mathrm{~cm}$ and a width of $25 \mathrm{~cm}$.

2. The shape of the packaging is rectangular, the material is transparent plastic tube, the color of the packaging design is simple, light and the product identity is written with a capital letter at the beginning of the word followed by lowercase letters.

3. The size of the letters on the product identity has a letter height of $1.5 \mathrm{~cm}$, a thickness of $0.25 \mathrm{~cm}$, a distance of two letters of $0.3 \mathrm{~cm}$, a width of letters, and a distance between two words of $1 \mathrm{~cm}$. 4. For decoration, mascot, or accessories on the packaging, including a description of the net weight of $500 \mathrm{gr}$ or kg, product description "Ikan Asin Talang", description of the trademark "UD. Wirna", and a picture of Talang salted fish.

4. The cost of making the selected design is Rp. 1000/package.

5. The advantage of the design chosen with the initial design (without design) is the addition of more attractive functions to increase buyer interest despite the increase in packaging prices.

\section{Conclusion}

Based on the results of research and discussion of packaging design criteria according to consumer desires, packaging that has a trademark has a net weight measurement, has a clear, attractive product identity, appropriate color gradation, typography, and appropriate font size. The highest priority on the existing criteria is to have a product identity with a priority factor of 0.323 , then trademark 0.142 , net weight size 0.138 , typography 0.118 , attractive 0.112 , font size 0.086 , and appropriate color 0.081 . The performance of each alternative is as follows: alternative 1 is 38.9 , alternative 2 is 30.4 and alternative 3 is 30.7 .

Based on the results of the calculation of the value, the design of the salted fish packaging design talang alternative 1 (ABDE) is a packaging design with packaging materials made of transparent plastic, the colors used are bright patterns, the packaging is rectangular and uses capital letters and lowercase letters. This selected alternative design has a value of 0.039 . This value is obtained from the performance of 38.9 and the cost of Rp. 1000 packs.

\section{References}

[1] Z. Zakiyuddin and F. Reynaldi, "The Phenomenon of 'Badapu' Tradition with Nutritional Status in Postpartum Mothers in West Aceh,” Int. J. Eng. Sci. Inf. Technol., vol. 1, no. 1, 2021, doi: 10.52088/ijesty.v1i1.42.

[2] D. A. Bedward, R. M. Brinston, and J. Kotler, "Converting from ETO to radiation sterilization: Educating the medical supply industry," Radiat. Phys. Chem., vol. 46, no. 4, Part 1, pp. 443-448, 1995, doi: https://doi.org/10.1016/0969-806X(95)00190-9.

[3] S. H. Ang, S. M. Leong, and P. Kotler, "The Asian Apocalypse: Crisis Marketing for Consumers and Businesses," Long Range Plann., vol. 33, no. 1, pp. 97-119, 2000, doi: https://doi.org/10.1016/S0024-6301(99)00100-4.

[4] Q. Wang, D. Wu, G. Li, and W. Gao, "A virtual model architecture for engineering structures with Twin Extended Support Vector Regression (T-X-SVR) method," Comput. Methods Appl. Mech. Eng., vol. 386, p. 114121, 2021, doi: https://doi.org/10.1016/j.cma.2021.114121.

[5] J. Galbraith, "Values in early-stage climate engineering: The ethical implications of "doing the research," Stud. Hist. Philos. Sci. Part A, vol. 86, pp. 103-113, 2021, doi: https://doi.org/10.1016/j.shpsa.2021.01.009.

[6] L. P. Tuti Ariani, "The Effect Of Repetition Sprint Training Method Combined With The Level Of Physical Fitness Toward The Speed Of 100 Meter Run,” Int. J. Eng. Sci. Inf. Technol., vol. 1, no. 3, 2021, doi: 10.52088/ijesty.v1i3.89.

[7] O. Oktamianiza, D. Maisa Putra, Y. Yulia, A. Fahira, and A. Afridon, "Analysis of Differences in Tariff for Health Service Based on Sustability of Diagnosis on Admision and Summary Discharge Form with INA-CBGs Verification," Int. J. Eng. Sci. Inf. Technol., vol. 1, no. 3, 2021, doi: 10.52088/ijesty.v1i3.114.

[8] Mardiana and S. Wardah, "Proposed Lome (Harpodon Nehereus) Salted Fish Packaging Design Using the Value Enginering Method," J. Tenik Ind. UNISI, vol. 1, no. 1, pp. 11-19, 2017.

[9] N. Sylvia, Y. Yunardi, H. Husni, and A. Muslim, "Simulation of CO2 Gas Adsorption Process Flow at Cyclone Gas Outlet in Palm Oil Mills Using Computation Fluid Dynamic Simulation," Int. J. Eng. Sci. Inf. Technol., vol. 1, no. 3, 2021, doi: 10.52088/ijesty.v1i3.112.

[10] R. Dewi, N. Sylvia, and M. Riza, "The Effect of Rice Husk and Saw Dusk Filler on Mechanical Property of Bio Composite from Sago Starch,” Int. J. Eng. Sci. Inf. Technol., vol. 1, no. 3, 2021, doi: 10.52088/ijesty.v1i3.113.

[11] S. Permana, M. Andriani, and D. Dewiyana, "Production Capacity Requirements Planning Using The Capacity Method Requirement Planning,” Int. J. Eng. Sci. Inf. Technol., vol. 1, no. 4, 2021, doi: 10.52088/ijesty.v1i4.165.

[12] R. Mirsa, M. Muhammad, F. Fidyati, E. Saputra, and M. Rumiza, "Space Transformation in Residential House Small Entrepreneurs Banana Sale," Int. J. Eng. Sci. Inf. Technol., vol. 1, no. 4, 2021, doi: 10.52088/ijesty.v1i4.167. 
[13] R. Hidayat, A. Arendra, and S. Akhmad, "Bread Fermentation Machine Development Using Value Engineering (Ve) Approach," Spektrum Ind., vol. 12, no. 1, p. 1, 2014, doi: 10.12928/si.v12i1.1645.

[14] J. Heinzel et al., "Use of the CatWalk gait analysis system to assess functional recovery in rodent models of peripheral nerve injury - a systematic review," J. Neurosci. Methods, vol. 345, p. 108889, 2020, doi: https://doi.org/10.1016/j.jneumeth.2020.108889.

[15] G. Tenaglia, F. Romanelli, S. La Rovere, G. M. Polli, L. Gabellieri, and M. Valisa, "Functional Analysis for the diagnostic systems to support the exploitation of the Divertor Tokamak Test facility," Fusion Eng. Des., vol. 170, p. 112692, 2021, doi: https://doi.org/10.1016/j.fusengdes.2021.112692.

[16] S. Martí-García, F. Relinque-Medina, M. Á. Fernández-Borrero, and O. Vázquez-Aguado, "Structural and functional analysis of cases of family treatment treated in the public social services system," Heliyon, vol. 7, no. 5, p. e06825, 2021, doi: https://doi.org/10.1016/j.heliyon.2021.e06825.

[17] S. T. Hornum and S. Bolwig, "A functional analysis of the role of input suppliers in an agricultural innovation system: The case of small-scale irrigation in Kenya," Agric. Syst., vol. 193, p. 103219, 2021, doi: https://doi.org/10.1016/j.agsy.2021.103219.

[18] T. Imankulov, B. Daribayev, and S. Mukhambetzhanov, "Comparative analysis of parallel algorithms for solving oil recovery problem using cuda and opencl," Int. J. Nonlinear Anal. Appl., vol. 12, no. 1, 2021, doi: 10.22075/IJNAA.2021.4809.

[19] C. Hendratmoko, B. Istiyanto, I. Ayu, and K. Rachmawati, "Development of Empowerment Models for Fish Processors to Increase Income (Case Study on Fish Processors in Cilacap Regency)," J. Paradig., vol. 12, no. 02, pp. 158-178, 2015.

[20] T. L. Saaty and E. Rokou, "How to prioritize inventions," World Pat. Inf., vol. 48, pp. 78-95, 2017, doi: https://doi.org/10.1016/j.wpi.2017.02.003.

[21] T. Saaty, "Neurons the decision makers, Part I: The firing function of a single neuron," Neural Networks, vol. 86, pp. 102-114, 2017, doi: https://doi.org/10.1016/j.neunet.2016.04.003.

[22] T. Saaty, "Part 2-The firings of many neurons and their density; the neural network its connections and field of firings," Neural Networks, vol. 86, pp. 115-122, 2017, doi: https://doi.org/10.1016/j.neunet.2016.04.004.

[23] Binti Ida Umaya, "Penerapan value engineering (VE) sebagai pemilihian alternatiif pembuatan kantong tas belanja wanita dengan konsep green product," Univ. Nusant. PGRI Kediri, vol. 01, pp. 1-7, 2017.

[24] A. Rondini, M. Bertoni, and G. Pezzotta, "At the origins of Product Service Systems: Supporting the concept assessment with the Engineering Value Assessment method," CIRP J. Manuf. Sci. Technol., vol. 29, pp. 157-175, 2020, doi: https://doi.org/10.1016/j.cirpj.2018.08.002.

[25] P. H. P. Setti, O. Canciglieri Junior, and C. C. A. Estorilio, "Integrated product development method based on Value Engineering and design for assembly concepts," J. Ind. Inf. Integr., vol. 21, p. 100199, 2021, doi: https://doi.org/10.1016/j.jii.2020.100199.

[26] J. Tao and S. Yu, "Product Life Cycle Design for Sustainable Value Creation: Methods of Sustainable Product Development in the Context of High Value Engineering," Procedia CIRP, vol. 69, pp. 25-30, 2018, doi: https://doi.org/10.1016/j.procir.2017.11.099.

[27] K. Pelzer et al., "Penerapan value Engineering(Ve)Sebagai Pemilihan Alternatif Pembuatan Kantong Tas Belanja Wanita Dengan Konsep Green Product," Solid State Ionics, vol. 2, no. 1, pp. 1-10, 2017.

[28] L. T. Haryanto, "The Redesign Of Walker For Pasca- Stroke Patient Use A Value Engineering Method,” 2015.

[29] S. Nugroho, D. Pujotomo, and A. Gitakusuma, "Aplikasi Value Engineering Untuk Mengatasi Value Problem Pada Produk Foodcart Studi Kasus Di Master Gerobak,” Ind. Eng., vol. 7, no. 3, pp. 1-9, 2018.

[30] H. Kawakami, O. Katai, T. Sawaragi, T. Konishi, and S. Iwai, "Knowledge acquisition method for conceptual design based on value engineering and axiomatic design theory," Artif. Intell. Eng., vol. 10, no. 3, pp. 187-202, 1996, doi: https://doi.org/10.1016/0954-1810(95)00028-3. 